\title{
Lung Cancer Pathologic Regional Lymph Nodes TNM Finding v6
}

National Cancer Institute

\section{Source}

National Cancer Institute. Lung Cancer Pathologic Regional Lymph Nodes TNM Finding

v6. NCI Thesaurus. Code C60981.

A pathologic finding about one or more characteristics of lung cancer, following the rules

of the TNM AJCC v6 classification system as they pertain to staging of regional lymph nodes. 